\title{
A CASE STUDY ON MAXIMISING THE PROFITABILITY OF A FORM FILL AND SEAL MACHINE BY OPTIMISING INTERRUPTION INTERVALS
}

\author{
P.J. Vlok ${ }^{1}$ and C.J. Fourie ${ }^{2}$ \\ ${ }^{1}$ Department of Industrial Engineering \\ University of Stellenbosch, South Africa \\ pjvlok@sun.ac.za \\ ${ }^{2}$ Department of Industrial Engineering \\ University of Stellenbosch, South Africa \\ cjf@sun.ac.za
}

\begin{abstract}
The practice of delivering consumer liquids in sachets, as opposed to alternative disposable packaging, has gained significant ground in the market in recent years because of environmental considerations, the cost benefit of sachets, and the relatively simple machinery required to produce sachets. In this paper, data obtained from a form, fill and seal (FFS) sachet producing machine is analysed for financial feasibility. A statistical model is fitted to the data to optimise production interruptions, and the model's relevance and value is confirmed on a second data set obtained from the same machine.
\end{abstract}

\section{OPSOMMING}

Die gebruik om verbruikersvloeistowwe in sakkies eerder as alternatiewe weggooibare verpakkingsmateriaal af te lewer het beduidende vooruitgang gemaak in die mark in die onlangse verlede as gevolg van omgewingsvriendelikheid, die koste-voordeel van sakkies, en die relatief eenvoudige toerusting wat benodig word vir die produksie van sakkies. In hierdie artikel word data wat verkry is van 'n Vorm, Vul en Seël (VVS) sakkie vervaardigingsmasjien geanaliseer vir ekonomiese lewensvatbaarheid. 'n Statistiese model word gepas oor die data om die produksie-onderbrekings te optimeer, en die model se toepaslikheid en waarde word bevestig met ' $n$ tweede data-stel verkry van dieselfde masjien. 


\section{INTRODUCTION}

The practice of delivering consumer liquids such as water, milk, juice, and cooking oil in sachets instead of plastic bottles has gained significant ground in recent years. In Nigeria, for example, the supply of public drinking water is unreliable, and drinking water is sold to its 148 million people almost exclusively in sachets. Up to $70 \%$ of the population in Lagos State (with 17 million people) get their daily water from sources other than the state municipalities. The production, marketing, and consumption of sachet water have increased tremendously, and several brands of water sachets are marketed in Nigeria and neighbouring developing nations. Packaging in smaller, affordable quantities has proved particularly successful, according to Dada[1].

The Austrialian Department of Trade and Industry [2] studied the introduction of higher value consumer products in sachets, specifically shampoo, in India. Not only did the market size of shampoo grow, but sachets account for nearly $75 \%$ of shampoo sales because a premium product is readily affordable.

Reasons for the sachet market gaining ground on plastic bottles and other disposable containers include the significant price advantage, the relatively simple and inexpensive equipment required for producing liquids in sachets, and the reduced carbon footprint generated by sachets, compared with - for example - plastic bottles, according to KwakyeNuako et al [3]. One disadvantage of sachet liquids is the inconvenience of use. This explains the relative absence of sachets in consumer liquids produced for first world markets. However, for people of a lower socio-economic class, price and economy are the most important reasons for selecting sachets.

The business model on which selling sachet liquids is based is one of high volume production at fairly low margins. A basic sachet machine is able to produce around 200 one litre sachets per hour, while a more advanced model can reach production rates of as high as 400 one litre sachets per hour. In a sold out market the gross margin on sachet consumer liquids is typically around $10 \%$ to $15 \%$, which means that production interruptions must be avoided.

Production of sachet liquids is mostly done with a form, fill and seal (FFS) machine. FFS machines are relatively inexpensive and simple to operate. Almost no mechanical maintenance is required to operate an FFS machine, and downtime due to maintenance is unusual. On the other hand, replacing consumables on FFS machines - e.g. Teflon strips and cut wires - causes regular production interruptions that have to be minimised (or at least optimised) given the low margins in the business model.

This paper describes the analysis of production data obtained from an FFS machine producing sachet liquids in a sold out market. Unmanaged production interruptions made the business unfeasible, but through statistical analysis an interruption strategy was devised that resulted in a profitable business. The paper describes the original data set and the inherent goal function, as well as analysis methods and a recommended improvement strategy. Data obtained after implementing the improvement strategy is also compared with the goals to validate the value of the analysis.

\section{PROBLEM DEFINITION: PRODUCTION INTERRUPTIONS ON A VERTICAL FORM, FILL AND SEAL MACHINE}

\subsection{A typical form, fill and seal process}

Vertical form, fill and seal (FFS) packaging is a type of automated assembly-line product packaging system commonly used in the packaging industry for food and liquids. The machine constructs plastic bags out of a flat roll of plastic film while simultaneously filling the bags with product and then sealing the filled bags. Both solids and liquids can be bagged using this packaging system. 
A typical machine is loaded with a continuous flat roll of plastic film that might have labelling and artwork applied to the exterior of the film. While unrolling, the film approaches the back of a long hollow conical tube, and when the centre of the plastic is near the tube, the outer edges of the film form flaps that wrap around the conical tube. The film is pulled downwards around the outside of the tube, and a vertical heat-sealing bar clamps on to the edges of the film, bonding it by melting the seam edges together. Teflon strips are stuck over the clamps to ensure smooth movement of the film and to prevent the film from being melted to the clamps.

To start the bagging process, a horizontal sealing bar clamps across the bottom edge of the tube, bonding the film together, and cutting off any film below. The sealed tube end is then lowered on to a precision weighing table, and the product to be bagged is dispensed through the long conical tube in the centre of the bag. Teflon strips are also stuck to the horizontal sealing bar for the same reasons as for the vertical sealing bar.

When the tare weight of the product-filled bag is reached, filling stops and the horizontal sealing bar seals the top of the bag, and simultaneously forms the bottom of the next bag above. This bag is then cut off from the tube, and is now a sealed package ready to advance onward into the product boxing and shipping processes. Cutting is done by a cut wire embedded in the horizontal sealing bar.

\subsection{Consumables on an FFS machine}

FFS machines require very limited maintenance on mechanical moving parts such as the electrical motors, cams, gears, or roller element bearings. Machines do, however, have consumables in the form of the Teflon strips on the vertical and horizontal sealing bars, as well as a cut wire embedded in the horizontal sealing bar, which have to be replaced regularly during production.

Both consumables on the FFS machine that was used to obtain the data for this study are relatively inexpensive: Teflon strips cost around R150 per change, and the cut wire cost about R200. A much more significant cost is that of production interruptions due to the replacements of the consumables. More detail on the cost of production loss is given in the sections below.

\subsection{The business model of producing sachet liquids}

The FFS machine investigated in this paper is used to produce one litre sachets filled with inexpensive cold drink, sold to low income consumers. The machine was acquired for $\mathrm{R} 110,000$. A gross income of R0.80 is achieved per sachet. Gross income is defined here as the direct contribution of each sachet to the revenue stream, i.e. the selling price less the cost of energy, plastic, and the liquid. The gross income less the cost of consumables is defined as the gross profit.

Selling sachets of cold drink to low income consumers is a high volume, low margin business, and fast uninterrupted production runs are vital in the business model. The FFS machine under consideration has the capacity to produce 250 one litre sachets per hour. In theory that should contribute a gross income of R200 per hour. In reality this was found not to be the case, due to the interruptions required to replace Teflon strips and the cut wire.

Teflon strips are expected to last for 1,800 sachets at a cost of R150, and the cut wire should perform 2,400 cuts at a cost of R200, according to their respective manufacturers. The time required to replace the consumables depends on the mode of replacement. If replacement is done in a preventive sense - e.g. before melting due to over-use significantly less time is required for replacement compared with replacing the items in a corrective manner - e.g. after melting due to over-use. Table 1 below summarises the replacement times required for the consumables in numbers of hours. 


\begin{tabular}{|l|c|c|}
\cline { 2 - 3 } \multicolumn{1}{c|}{} & \multicolumn{2}{c|}{ Mode of replacement } \\
\cline { 2 - 3 } \multicolumn{1}{c|}{} & Preventive (h) & Corrective (h) \\
\hline Teflon strips & 1 & 4 \\
\hline Cut wire & 2 & 3.5 \\
\hline
\end{tabular}

Table 1: Replacement times required for consumables

The manufacturer of the FFS machine recommends that the consumables are always run to failure for the maximum overall production over the long term. Failure is defined as the event when the Teflon strips or the cut wire start melting due to wear, and therefore produce leaking sachets. Failure on both consumables happens instantaneously and a failure event is clearly defined and visible.

Using the time and cost information above, a projection was made that the machine could be operated at a gross profit of R3,300 per week. The owner of the cool drink sachet business decided to acquire the machine to determine if this gross profit was achievable. The simplicity of the machine, the solid market for inexpensive cool drink sachets, and the ability to scale the business up, made this an interesting proposition. In reality it turned out to be more complex.

\subsection{Production data}

Production data was collected for 30 consecutive production interruptions or failures. Table 2 below summarises the data with the failure event number as well as the number of sachets produced between failures.

\begin{tabular}{|c|c|}
\hline $\begin{array}{c}\text { Failure } \\
\text { no. }\end{array}$ & $\begin{array}{c}\text { No. of sachets } \\
\text { produced }\end{array}$ \\
\hline 1 & 1,198 \\
\hline 2 & 162 \\
\hline 3 & 2,319 \\
\hline 4 & 123 \\
\hline 5 & 2,917 \\
\hline 6 & 230 \\
\hline 7 & 1,774 \\
\hline 8 & 139 \\
\hline 9 & 2,873 \\
\hline 10 & 372 \\
\hline 11 & 2,844 \\
\hline 12 & 102 \\
\hline 13 & 1,680 \\
\hline 14 & 389 \\
\hline 15 & 1,989 \\
\hline
\end{tabular}

\begin{tabular}{|c|c|}
\hline $\begin{array}{c}\text { Failure } \\
\text { no. }\end{array}$ & $\begin{array}{c}\text { No. of sachets } \\
\text { produced }\end{array}$ \\
\hline 16 & 292 \\
\hline 17 & 2,902 \\
\hline 18 & 219 \\
\hline 19 & 1,198 \\
\hline 20 & 216 \\
\hline 21 & 2,428 \\
\hline 22 & 544 \\
\hline 23 & 2,973 \\
\hline 24 & 529 \\
\hline 25 & 2,172 \\
\hline 26 & 195 \\
\hline 27 & 2,092 \\
\hline 28 & 265 \\
\hline 29 & 2,564 \\
\hline 30 & 307 \\
\hline
\end{tabular}

Table 2: Production data for 30 failures

Note that all the uneven failure numbers represent failure of the Teflon strips, while the even numbers denote failure of the cut wire. The Teflon strips failed without exception before the cut wire in the data set. 
The FFS machine manufacturer's recommendation always to replace consumables on failure was followed for the data set in Table 2. This means that for every failure (Teflon strips or cut wire), the FFS machine was out of operation for the corrective times in Table 1. A breakdown of the actual business performance is shown in Table 3, using a gross income of R0.80 per sachet and a production capacity of 250 sachets per hour.

\begin{tabular}{|l|r|r|r|}
\cline { 2 - 4 } \multicolumn{1}{c|}{} & \multicolumn{1}{c|}{ Qty } & \multicolumn{1}{c|}{ Unit } & $\begin{array}{c}\text { Income/ } \\
\text { Expense }\end{array}$ \\
\hline Gross income & 38,010 & 0.8 & $\mathrm{R} 30,408$ \\
\hline Cost of Teflon strips & 15 & 150 & $(\mathrm{R} 2,250)$ \\
\hline Cost of cut wires & 15 & 200 & $(\mathrm{R} 3,000)$ \\
\hline $\begin{array}{l}\text { Cost of downtime to } \\
\text { replace Teflon strips }\end{array}$ & 15 & 4 & $(\mathrm{R} 12,000)$ \\
\hline $\begin{array}{l}\text { Cost of downtime to } \\
\text { replace cut wires }\end{array}$ & 15 & 4 & $(\mathrm{R} 10,500)$ \\
\hline Gross profit/loss & & & $\mathrm{R} 2,658$ \\
\hline Gross profit/loss per sachet & & $\mathrm{R} 0.07$ \\
\hline
\end{tabular}

Table 3: Business performance of the FFS machine when replacing consumables only on failure

The data in Table 2 represents an overall mission time (downtime plus uptime of the machine) of 11.02 days. Generating a gross profit of R2,658 over 11 days is simply too low to be a sustainable business, given the capital input required for the machine. It is necessary to increase the profitability by optimising production intervals as well as changing the mode of replacing consumables (preventive or corrective) for the business venture to survive.

\section{MAXIMISING HISTORIC PROFITABILITY BY OPTIMISING INTERRUPTION INTERVALS}

A simple eyeball analysis of the data in Table 2 suggests that the strategy of running both consumables to failure (as recommended by the manufacturer) does not make sense. The historic mean time between failure (MTBF) of the Teflon strips was 2,262 sachets; the MTBF of the cut wire was 2,534 sachets, or 272 sachets more than the Teflon strips. Taking the machine out of operation on average after 2,534 sachets, and again on average 272 sachets later, intuitively seems unnecessarily expensive. In this section, an evaluation of a strategy to replace both consumables on failure of the Teflon strips, and an evaluation of replacing both consumables at a predetermined preventive interval, is done on the historic data of Table 2 to determine the viability of modeling the data statistically for future production runs.

\subsection{Replace both consumables on failure of the Teflon strips}

Replacing both consumables on the failure of the Teflon strips implies that the cost of a corrective failure on the Teflon strips still applies; but it has the advantage that only the cost of preventive replacement of the cut wire applies. Unfortunately it is not possible to perform the replacement actions simultaneously when the machine is shut down, and following this strategy means that the machine is effectively unavailable for 4 hours (time of corrective action on the Teflon strips) plus 2 hours (time of preventive action on the cut wire).

Table 4 shows a modified version of the data in Table 2. Only the uneven failure events (failures of Teflon trips) are considered to calculate the total cost of every interruption. 


\begin{tabular}{|r|r|r|r|r|r|}
\cline { 2 - 6 } \multicolumn{1}{c|}{} & $\begin{array}{r}\text { Nr of } \\
\text { sachets }\end{array}$ & $\begin{array}{c}\text { Production } \\
\text { income lost }\end{array}$ & $\begin{array}{c}\text { Cost of } \\
\text { Teflon } \\
\text { strips }\end{array}$ & $\begin{array}{c}\text { Cost of } \\
\text { cut wire }\end{array}$ & $\begin{array}{l}\text { Total cost of } \\
\text { interruption }\end{array}$ \\
\hline 1 & 1,198 & $\mathrm{R} 1,200$ & $\mathrm{R} 150$ & $\mathrm{R} 200$ & $\mathrm{R} 1,550$ \\
\hline 3 & 2,319 & $\mathrm{R} 1,200$ & $\mathrm{R} 150$ & $\mathrm{R} 200$ & $\mathrm{R} 1,550$ \\
\hline 5 & 2,917 & $\mathrm{R} 1,200$ & $\mathrm{R} 150$ & $\mathrm{R} 200$ & $\mathrm{R} 1,550$ \\
\hline 7 & 1,774 & $\mathrm{R} 1,200$ & $\mathrm{R} 150$ & $\mathrm{R} 200$ & $\mathrm{R} 1,550$ \\
\hline 9 & 2,873 & $\mathrm{R} 1,200$ & $\mathrm{R} 150$ & $\mathrm{R} 200$ & $\mathrm{R} 1,550$ \\
\hline 11 & 2,844 & $\mathrm{R} 1,200$ & $\mathrm{R} 150$ & $\mathrm{R} 200$ & $\mathrm{R} 1,550$ \\
\hline 13 & 1,680 & $\mathrm{R} 1,200$ & $\mathrm{R} 150$ & $\mathrm{R} 200$ & $\mathrm{R} 1,550$ \\
\hline 15 & 1,989 & $\mathrm{R} 1,200$ & $\mathrm{R} 150$ & $\mathrm{R} 200$ & $\mathrm{R} 1,550$ \\
\hline 17 & 2,902 & $\mathrm{R} 1,200$ & $\mathrm{R} 150$ & $\mathrm{R} 200$ & $\mathrm{R} 1,550$ \\
\hline 19 & 1,198 & $\mathrm{R} 1,200$ & $\mathrm{R} 150$ & $\mathrm{R} 200$ & $\mathrm{R} 1,550$ \\
\hline 21 & 2,428 & $\mathrm{R} 1,200$ & $\mathrm{R} 150$ & $\mathrm{R} 200$ & $\mathrm{R} 1,550$ \\
\hline 23 & 2,973 & $\mathrm{R} 1,200$ & $\mathrm{R} 150$ & $\mathrm{R} 200$ & $\mathrm{R} 1,550$ \\
\hline 25 & 2,172 & $\mathrm{R} 1,200$ & $\mathrm{R} 150$ & $\mathrm{R} 200$ & $\mathrm{R} 1,550$ \\
\hline 27 & 2,092 & $\mathrm{R} 1,200$ & $\mathrm{R} 150$ & $\mathrm{R} 200$ & $\mathrm{R} 1,550$ \\
\hline 29 & 2,564 & $\mathrm{R} 1,200$ & $\mathrm{R} 150$ & $\mathrm{R} 200$ & $\mathrm{R} 1,550$ \\
\hline Totals: & 33,924 & $\mathrm{R} 18,000$ & $\mathrm{R} 2,250$ & $\mathrm{R} 3,000$ & $\mathrm{R} 23,250$ \\
\hline
\end{tabular}

Table 4: Modified data set, considering only failure events of Teflon strips

Using the scenario in Table 4, it is possible to evaluate hypothetical business performance of the FFS machine comparable to the evaluation of Table 3.

\begin{tabular}{|l|r|r|r|}
\cline { 2 - 4 } \multicolumn{1}{c|}{} & \multicolumn{1}{c|}{ Qty } & Unit & $\begin{array}{c}\text { Income/ } \\
\text { expense }\end{array}$ \\
\hline Gross income & 33,924 & 0.8 & $\mathrm{R} 27,139$ \\
\hline Cost of Teflon strips & 15 & 150 & $(\mathrm{R} 2,250)$ \\
\hline Cost of cut wires & 15 & 200 & $(\mathrm{R} 3,000)$ \\
\hline $\begin{array}{l}\text { Cost of downtime to } \\
\text { replace Teflon strips }\end{array}$ & 15 & 4 & $(\mathrm{R} 12,000)$ \\
\hline $\begin{array}{l}\text { Cost of downtime to } \\
\text { replace cut wires }\end{array}$ & 15 & 2 & $(\mathrm{R} 6,000)$ \\
\hline Gross profit/loss & & & $\mathrm{R} 3,889$ \\
\hline Gross profit/loss per sachet & & $\mathrm{R} 0.11$ \\
\hline
\end{tabular}

Table 5: Hypothetical business performance of the FFS machine when replacing both consumables on failure of the Teflon strips

Table 5 shows an improvement of R0.04 per sachet (or 57\%) on the gross profit relative to the actual data. This is the first indication that the manufacturer's strategy might not lead to the optimal business performance of the FFS machine.

\subsection{Replace both consumables on a preventive basis or on failure of the Teflon strips}

In this section an optimal preventive interruption instant, $X_{p}$ (measured in number of sachets), is calculated for the original data in Table 2 to maximise the gross profit. Gross 
profit as a function of $X_{p}$ was defined as the goal function in a numerical optimisation routine. The optimisation revealed that a maximum for gross profit exists at $X_{p}=2,843$. Table 6 shows what the original data set of Table 2 would have looked like if the preventive rule had been implemented before collecting the data. Asterisks next to the interruption numbers indicate where the preventive replacement rule would have been implemented.

\begin{tabular}{|r|r|r|r|r|r|}
\hline \multicolumn{2}{|r|}{ No, of sachets } & $\begin{array}{c}\text { Production } \\
\text { income lost }\end{array}$ & $\begin{array}{c}\text { Cost of } \\
\text { Teflon } \\
\text { strips }\end{array}$ & $\begin{array}{c}\text { Cost of cut } \\
\text { wire }\end{array}$ & Total cost \\
\hline 1 & 1,198 & $\mathrm{R} 1,200$ & $\mathrm{R} 150$ & $\mathrm{R} 200$ & $\mathrm{R} 1,550$ \\
\hline 3 & 2,319 & $\mathrm{R} 1,200$ & $\mathrm{R} 150$ & $\mathrm{R} 200$ & $\mathrm{R} 1,550$ \\
\hline $5^{*}$ & 2,844 & $\mathrm{R} 600$ & $\mathrm{R} 150$ & $\mathrm{R} 200$ & $\mathrm{R} 950$ \\
\hline 7 & 1,774 & $\mathrm{R} 1,200$ & $\mathrm{R} 150$ & $\mathrm{R} 200$ & $\mathrm{R} 1,550$ \\
\hline $9^{*}$ & 2,844 & $\mathrm{R} 600$ & $\mathrm{R} 150$ & $\mathrm{R} 200$ & $\mathrm{R} 950$ \\
\hline $11^{*}$ & 2,844 & $\mathrm{R} 600$ & $\mathrm{R} 150$ & $\mathrm{R} 200$ & $\mathrm{R} 950$ \\
\hline 13 & 1,680 & $\mathrm{R} 1,200$ & $\mathrm{R} 150$ & $\mathrm{R} 200$ & $\mathrm{R} 1,550$ \\
\hline 15 & 1,989 & $\mathrm{R} 1,200$ & $\mathrm{R} 150$ & $\mathrm{R} 200$ & $\mathrm{R} 1,550$ \\
\hline $17^{*}$ & 2,844 & $\mathrm{R} 600$ & $\mathrm{R} 150$ & $\mathrm{R} 200$ & $\mathrm{R} 950$ \\
\hline 19 & 1,198 & $\mathrm{R} 1,200$ & $\mathrm{R} 150$ & $\mathrm{R} 200$ & $\mathrm{R} 1,550$ \\
\hline 21 & 2,428 & $\mathrm{R} 1,200$ & $\mathrm{R} 150$ & $\mathrm{R} 200$ & $\mathrm{R} 1,550$ \\
\hline $23^{*}$ & 2,844 & $\mathrm{R} 600$ & $\mathrm{R} 150$ & $\mathrm{R} 200$ & $\mathrm{R} 950$ \\
\hline 25 & 2,172 & $\mathrm{R} 1,200$ & $\mathrm{R} 150$ & $\mathrm{R} 200$ & $\mathrm{R} 1,550$ \\
\hline 27 & 2,092 & $\mathrm{R} 1,200$ & $\mathrm{R} 150$ & $\mathrm{R} 200$ & $\mathrm{R} 1,550$ \\
\hline 29 & 2,564 & $\mathrm{R} 1,200$ & $\mathrm{R} 150$ & $\mathrm{R} 200$ & $\mathrm{R} 1,550$ \\
\hline Totals: & 33,634 & $\mathrm{R} 15,000$ & $\mathrm{R} 2,250$ & $\mathrm{R} 3,000$ & $\mathrm{R} 20,250$ \\
\hline
\end{tabular}

Table 6: Modified data set where preventive replacements of both consumables are performed after producing 2,843 sachets or failure of the Teflon strips

As before, the hypothetical business performance of the FFS machine can be evaluated, based on the data in Table 6 . Table 7 below shows the summary.

\begin{tabular}{|l|r|r|r|}
\hline \multicolumn{2}{|c|}{ Qty } & \multicolumn{1}{c|}{ Unit } & Income/expense \\
\hline Gross income & 33,634 & R0.8 & R26,907 \\
\hline Cost of Teflon strips & 15 & 150 & (R2,250) \\
\hline Cost of cut wires & 15 & 200 & (R3,000) \\
\hline $\begin{array}{l}\text { Cost of downtime to replace Teflon } \\
\text { strips preventively }\end{array}$ & 5 & 1 & (R1,000) \\
\hline $\begin{array}{l}\text { Cost of downtime to replace Teflon } \\
\text { strips correctively }\end{array}$ & 10 & 4 & (R8,000) \\
\hline $\begin{array}{l}\text { Cost of downtime to replace cut wires } \\
\text { preventively }\end{array}$ & 15 & 2 & (R6,000) \\
\hline Gross profit/loss & & & R6,657 \\
\hline Gross profit/loss per sachet & & R0.20 \\
\hline
\end{tabular}

Table 7: Hypothetical business performance of the FFS machine when replacing both consumables after producing 2,843 sachets or on failure of the Teflon strips 
By using the hypothetical optimal preventive interruption strategy, a significant increase to the gross profit - compared with the actual situation (170\%) and the strategy in Section 3.1. $(82 \%)$ - was achieved. This observation justifies researching statistical models to determine the optimal value for $X_{p}$ for future maximum profitability.

\section{MAXIMISING FUTURE PROFITABILITY BY OPTIMISING PREVENTIVE INTERRUPTION INTERVALS}

In Section 3, hypothetical strategies for maximising historical profitability were considered. This is useful for investigative research, but it does not necessarily have any relevance for future data sets. In this section the data is analysed statistically to determine a strategy that is valid for future data sets.

The assumption is made that an optimised preventive interruption to replace both consumables based on the failure data of the Teflon strips alone will lead to the maximum profitability of the FFS machine. There is no evidence in the data to suggest the contrary.

\subsection{Data characteristics and modelling approach}

Life time models summarised by Crowder et al. [4] and Andersen [5] were researched to determine which statistical technique is most appropriate to represent the data in Table 2. No explanatory variables or covariates are available for the data set, which means that advanced life time models such as proportional hazards models, age setback models, and extended hazard regression models discussed and summarised by Jardine et al. [6] and Etezadi-Amoli [7] are not applicable in this analysis.

Ascher and Feingold [8] describe a roadmap to select the most appropriate model class for representing life time data without explanatory variables such as the data set in Table 2 . The first step would be to order the data in chronological order to determine whether an underlying trend exists. Only the data of the Teflon strips will be considered, as mentioned before. The Laplace Trend test (originally formulated in 1773 and described in Cox [9]) provides a robust trend test. It is given by

$U=\frac{\frac{\sum_{i=1}^{r-1} T_{i}}{r-1}-\frac{T_{r}}{2}}{T_{r} \sqrt{1 / 12(r-1)}}$

where $T_{i}$ is the $i^{\text {th }}$ cumulative observation instant and $r$ is the total number of observations. In the event where $U \geq 2$ there is strong evidence of shorter intervals between observations, while $U \leq 2$ indicates longer intervals. If $-1 \leq U \leq 1$ there is no evidence of an underlying trend in the data, and it is referred to as a non-committal data set. For the data set in Table 2 (considering only the Teflon strip failures), $U=-0.1601$.

If a trend were present in the data set, repairable systems theory would have been applicable to the data set. Calabria and Pulcini [10] as well as Kalbfleisch and Prentice [11] provide introductory material on repairable systems theory. Since no trend is present, this paper will not discuss repairable systems theory.

Ascher and Feingold [8] suggest as the next step to test for dependence in the data set, if possible, or adopt non-repairable systems theory. Cox and Lewis [12] have illustrated that dependence testing on failure data can only be performed with certainty on data sets with approximately 30 observations or more. Because the data set under consideration has only 15 observations, it was decided to adopt non-repairable systems theory. 
Non-repairable systems theory assumes that the data can be represented by a statistical distribution; and by using the distribution, statistical inferences can be made about future events. The Weibull distribution has been successfully used in life data analysis by many authors, including Huang et al. [13], because of its flexibility. The probability density function of the Weibull distribution is given by

$$
f_{X}(\boldsymbol{x})=\frac{\beta}{\eta}\left(\frac{\boldsymbol{x}}{\eta}\right)^{\beta-1} \cdot \exp \left(-\left(\frac{\boldsymbol{x}}{\eta}\right)^{\beta}\right)
$$

where $X$ is the independent variable (number of sachets produced), $x$ is the continuous representation of the independent variable, $\beta$ is the form parameter of the Weibull distribution and $\eta$ is the scale parameter of the Weibull distribution. For more theoretical background on the Weibull distribution, see Hines and Montgomery [14].

Once the paramters of the Weibull distribution have been determined, it is possible to construct a goal function for gross profit as a function of the optimal interruption instant, $X_{p}$.

\subsection{Parameter estimation of the Weibull distribution}

There are numerous methods to estimate the parameters of the Weibull distribution. One simple but generally applicable numerical method is based on maximising the likelihood function, i.e.

$$
\ln L(x, \beta, \eta)=\sum_{i=1}^{m}\left(\ln \frac{\beta}{\eta}+(\beta-1) \ln \frac{X_{i}}{\eta}\right)-\sum_{j=1}^{r}\left(\frac{X_{j}}{\eta}\right)^{\beta}
$$

where $m$ represents the total number of failure observations (implying no suspended observations exist) and $r$ denotes the total number of observations. There are no suspended observations (or observations with partial information) in the data set under consideration, and $m=r$ for this study. See Vlok et al. [15] for details on suspended observations.

Using this method for the data set yielded parameters of $\beta=4.701$ and $\eta=2,482$ for the Weibull distribution. The methods of Anderson and Darling [16] were used to confirm the good fit of the Weibull distribution to the data.

\subsection{Gross profit as a function of the optimal interruption instant}

With the parameters of the Weibull distribution available to represent the data in a continuous form, it is possible to represent gross profit as a function of the optimal interruption instant $X_{p}$. A simpler method to represent gross profit is to model cycle cost per produced unit (sachet) - i.e. the total cost between interruptions (preventive or corrective) per sachet. The gross cost of one life cycle of the FFS machine, if both consumables are replaced at failure of the Teflon strips or at preventive instant $X_{p}$, is expected to be

$$
C\left(X_{p}\right)=C_{p} \cdot R\left(X_{p}\right)+C_{f} \cdot F\left(X_{p}\right)
$$

where $R\left(X_{p}\right)$ is the cumulative probability up to instant $X_{p}$ (or probability of survival) and $F\left(X_{p}\right)$ is the complement of the cumulative probability up to instant $X_{p}$ (or the probability of failure). $C_{p}$ and $C_{f}$ denote the costs involved with preventive and corrective action 
respectively. It is also necessary to estimate the expected number of production units in a cycle; and this can be done by

$$
\mathrm{E}\left[X_{c}\right]=\left(X_{p}+a\right) \cdot R\left(X_{p}\right)+\left(\mathrm{E}\left[X_{r+1} \mid X_{r+1} \leq X_{p}\right]+b\right) \cdot F\left(X_{p}\right)
$$

where $a$ and $b$ denote the time required to perform preventive or corrective action respectively. $\mathrm{E}\left[X_{r+1} \mid X_{r+1} \leq X_{p}\right]$ is the expected time to failure of the Teflon strips for cycles where failure occurs before $X_{p}$.

The ratio of the previous two equations, $C_{X_{p}}$, provides an estimate for the total cost per produced sachet as a function of $X_{p}$. After substituting $a=3, b=6, C_{f}=1,550$ and $C_{p}=950, C_{X_{p}}$ can calculated for a range of values for $X_{p}$ and is shown below as Figure 1.

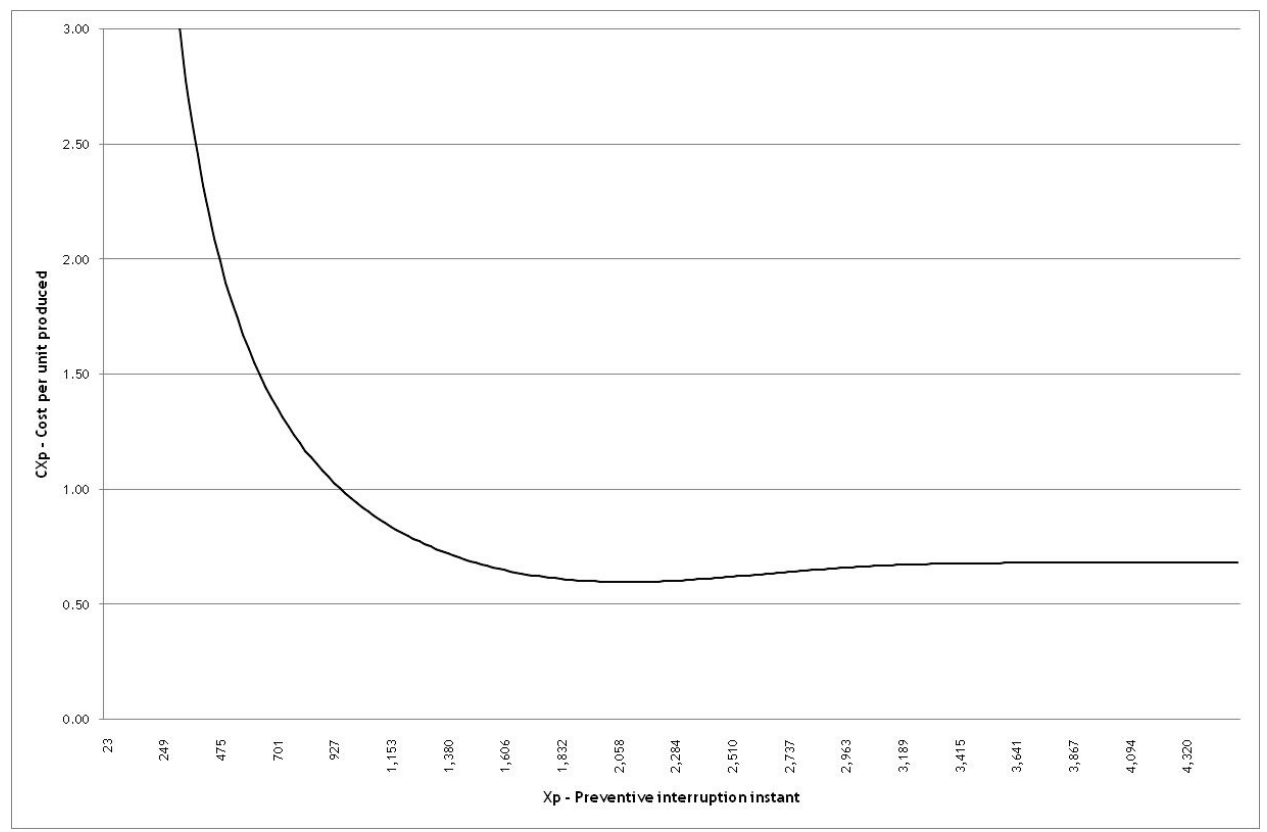

Figure 1: Cost per unit produced as a function of preventive interruption instant

$X_{p}$ has distinct minimum at $X_{p}=2,088 . C_{X_{p}}$ is significantly more sensitive for preventive action before the optimum than action after the optimum. This means that, over the long term, a cost of R0.59 per sachet (or a gross profit of R0.21 per sachet) will be achieved if the machine is always interrupted to replace both consumables after producing 2,088 sachets or at failure of the Teflon strips - whichever comes first. Integrating over the Weibull distribution between zero and 2,088 reveals that $68 \%$ of all Teflon strips will fail before producing 2,088 sachets.

\subsection{Evaluating the optimal production interruption interval on additional data}

An additional data set with the same number of observations was collected from the FFS machine with the preventive interruption strategy in place. The additional data set is shown in Table 8. Asterisks next to the failure number denote preventive interruptions. 


\begin{tabular}{|c|r|r|r|r|r|}
\hline \multicolumn{2}{|c|}{ No. of sachets } & $\begin{array}{r}\text { Production } \\
\text { income lost }\end{array}$ & $\begin{array}{c}\text { Cost of } \\
\text { Teflon } \\
\text { strips }\end{array}$ & $\begin{array}{c}\text { Cost of } \\
\text { cut wire }\end{array}$ & $\begin{array}{c}\text { Total } \\
\text { cost }\end{array}$ \\
\hline $1^{*}$ & 2,088 & $\mathrm{R} 600$ & $\mathrm{R} 150$ & $\mathrm{R} 200$ & $\mathrm{R} 950$ \\
\hline $2^{*}$ & 2,088 & $\mathrm{R} 600$ & $\mathrm{R} 150$ & $\mathrm{R} 200$ & $\mathrm{R} 950$ \\
\hline $3^{*}$ & 2,088 & $\mathrm{R} 600$ & $\mathrm{R} 150$ & $\mathrm{R} 200$ & $\mathrm{R} 950$ \\
\hline 4 & 1,253 & $\mathrm{R} 1,200$ & $\mathrm{R} 150$ & $\mathrm{R} 200$ & $\mathrm{R} 1,550$ \\
\hline 5 & 1,236 & $\mathrm{R} 1,200$ & $\mathrm{R} 150$ & $\mathrm{R} 200$ & $\mathrm{R} 1,550$ \\
\hline 6 & 1,262 & $\mathrm{R} 1,200$ & $\mathrm{R} 150$ & $\mathrm{R} 200$ & $\mathrm{R} 1,550$ \\
\hline $7^{*}$ & 2,080 & $\mathrm{R} 1,200$ & $\mathrm{R} 150$ & $\mathrm{R} 200$ & $\mathrm{R} 1,550$ \\
\hline $8^{*}$ & 2,088 & $\mathrm{R} 600$ & $\mathrm{R} 150$ & $\mathrm{R} 200$ & $\mathrm{R} 950$ \\
\hline 9 & 1,713 & $\mathrm{R} 1,200$ & $\mathrm{R} 150$ & $\mathrm{R} 200$ & $\mathrm{R} 1,550$ \\
\hline $10^{*}$ & 2,088 & $\mathrm{R} 600$ & $\mathrm{R} 150$ & $\mathrm{R} 200$ & $\mathrm{R} 950$ \\
\hline 11 & 1,163 & $\mathrm{R} 1,200$ & $\mathrm{R} 150$ & $\mathrm{R} 200$ & $\mathrm{R} 1,550$ \\
\hline $12^{*}$ & 2,088 & $\mathrm{R} 600$ & $\mathrm{R} 150$ & $\mathrm{R} 200$ & $\mathrm{R} 950$ \\
\hline $13^{*}$ & 2,088 & $\mathrm{R} 600$ & $\mathrm{R} 150$ & $\mathrm{R} 200$ & $\mathrm{R} 950$ \\
\hline $14^{*}$ & 2,088 & $\mathrm{R} 600$ & $\mathrm{R} 150$ & $\mathrm{R} 200$ & $\mathrm{R} 950$ \\
\hline 15 & 1,288 & $\mathrm{R} 1,200$ & $\mathrm{R} 150$ & $\mathrm{R} 200$ & $\mathrm{R} 1,550$ \\
\hline Totals: & 26,699 & $\mathrm{R} 13,200$ & $\mathrm{R} 2,250$ & $\mathrm{R} 3,000$ & $\mathrm{R} 18,450$ \\
\hline & & & & & \\
\hline
\end{tabular}

Table 8: Additional data set obtained from the FFS machine

\begin{tabular}{|c|c|c|c|c|}
\hline 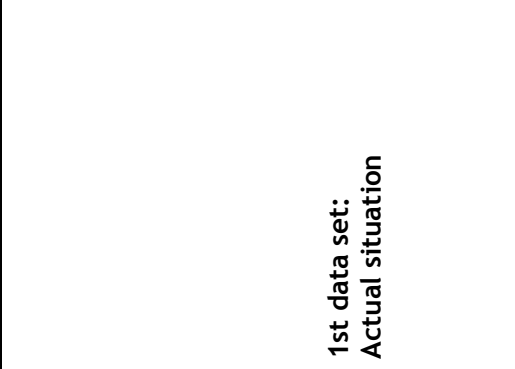 & & 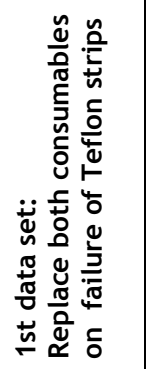 & 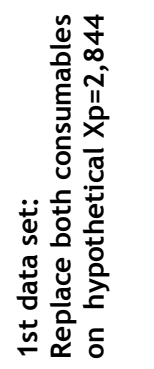 & 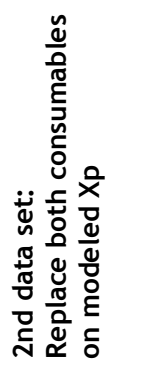 \\
\hline Number of sachets produced & 38,010 & 33,924 & 33,634 & 26,699 \\
\hline Gross income before consumables & $\mathrm{R} 30,408$ & $\mathrm{R} 27,139$ & $\mathrm{R} 26,907$ & $\mathrm{R} 26,210$ \\
\hline Cost of Teflon strips & $(\mathrm{R} 2,250)$ & $(\mathrm{R} 2,250)$ & $(\mathrm{R} 2,250)$ & $(\mathrm{R} 2,250)$ \\
\hline Cost of cut wires & $(\mathrm{R} 3,000)$ & $(\mathrm{R} 3,000)$ & $(\mathrm{R} 3,000)$ & $(\mathrm{R} 3,000)$ \\
\hline $\begin{array}{l}\text { Cost of downtime to replace Teflon } \\
\text { strips preventively }\end{array}$ & Ro & Ro & $(\mathrm{R} 1,000)$ & $(\mathrm{R} 1,600)$ \\
\hline $\begin{array}{l}\text { Cost of downtime to replace Teflon } \\
\text { strips correctively }\end{array}$ & $(\mathrm{R} 12,000)$ & $(\mathrm{R} 12,000)$ & $(\mathrm{R} 8,000)$ & $(\mathrm{R} 5,600)$ \\
\hline $\begin{array}{l}\text { Cost of downtime to replace cut } \\
\text { wires preventively }\end{array}$ & Ro & $(R 6,000)$ & $(\mathrm{R} 6,000)$ & $(\mathrm{R} 6,000)$ \\
\hline $\begin{array}{l}\text { Cost of downtime to replace cut } \\
\text { wires correctively }\end{array}$ & $(\mathrm{R} 10,500)$ & Ro & Ro & Ro \\
\hline Gross profit/loss & $\mathrm{R} 2,658$ & $\mathrm{R} 3,889$ & $\mathrm{R} 6,657$ & $\mathrm{R} 7,760$ \\
\hline Gross profit/loss per sachet & $\mathrm{R} 0.07$ & R0.11 & R0.20 & R0.29 \\
\hline
\end{tabular}

Table 9: Business comparison of all scenarios considered 
Production runs were interrupted eight times preventively, and failure occurred seven times. This means that $47 \%$ of the samples failed before the preventive interruption, which is slightly lower than the $68 \%$ expected by the Weibull distribution. The business performance for this particular data set is thus likely to be slightly higher than what might be expected over the long term.

Table 9 shows the comparative business performance of all of the scenarios evaluated in this paper.

The comparison in Table 9 clearly shows the advantage of using a preventive interruption. Gross profit per sachet for the second data set is $\mathrm{R0.22}$ or $285 \%$ better than for the first data set, where a pure run to failure approach was used. This performance is slightly higher than the gross profit of R0.21 per sachet expected by the Weibull distribution over the long term.

\section{CONCLUSION}

The analysis of the original data set shows unequivocally that a 'run to failure' strategy is not the most profitable management strategy for this particular machine and the conditions under which it is operated. Several different statistical techniques could have been employed to model the data and set the interruption strategy. Using a Weibull distribution to represent the data had a significant impact on the machine's profitability.

The technique described in this paper can be extended to develop a generic approach to other interruption strategies and preventive maintenance applications, and should be investigated.

\section{REFERENCES}

[1] Dada, A.C. 2009. Sachet water phenomenon in Nigeria, African Journal of Microbiology Research, 3(1), 015-021.

[2] Austrialian Department of Foreign Affairs and Trade. 2004. India's economy at the midnight hour: Australia's India strategy, Commonwealth of Australia, Australian Government Publishing Service.

[3] Kwakye-Nuako, G., Borketey, P., Mensah-Attipoe, I., Asmah, R. \& Ayeh-Kumi, P. 2007. Sachets in medicine, Ghana Medical Journal, 41(2), 62-67.

[4] Crowder, M.J., Kimber, A.C., Smith, R.L. \& Sweeting, T.J. 1991. Statistical analysis of reliability data, Chapman and Hall.

[5] Andersen, P.K. 1985. Counting process models for life history data: A review, Scandinavian Journal of Statistics, 12, 97-158.

[6] Jardine, A.K.S. \& Anderson, M. 1988. Use of concomitant variables for reliability estimation, Maintenance Management International 5, 135-140.

[7] Etezadi-Amoli, J. \& Ciampi, A. 1987. Extended hazard regression for censored survival data with covariates: A spline approximation for the baseline hazard function. Biometrics, 43, 181-192.

[8] Ascher, H.E. \& Feingold, H. 1984. Repairable systems reliability: Modeling, inference, misconceptions and their causes, Marcel Dekker.

[9] Cox, D.R. 1955. Some statistical methods connected with series of events, Journal of the Royal Statistical Society, 17, 129-164.

[10] Calabria, R. \& Pulcini, G. 2000. Inference and test in modeling the failure/repair process of repairable mechanical equipments. Reliability Engineering and System Safety, 67, 41-53.

[11] Kalbfleisch, J.D. \& Prentice, R.L. 1980. The statistical analysis of failure time data, New York: John Wiley \& Sons.

[12] Cox, D.R. \& Lewis, P.A. 1966. The statistical analysis of series of events, Metheun,London. 
[13] Huang, J., Miller, C.R. \& Okogbaa, O.G. 1995. Optimal preventive replacement intervals for the Weibull life distribution: Solutions and applications, Proceedings of the Annual Reliability and Maintenance Symposium, 370-377.

[14] Hines, W.W. \& Montgomery, D.C. 1980. Probability and statistics in engineering and management science ( $2^{\text {nd }} e d$.), John Wiley and Sons.

[15] Vlok, P.J., Coetzee, J.L., Banjevic, D., Jardine, A.K.S \& Makis, V. 2002. Optimal component replacement decisions using vibration monitoring and the Proportional Hazards Model. Journal for the Operational Research Society, 53, 2.

[16] Anderson, T.W. \& Darling, D.A. 1954. A test of goodness of fit. Journal of the American Statistical Association, 49, 765-769. 
http://sajie.journals.ac.za 